\title{
DIAGNOSIS OF VAGINAL INFECTION IN PREGNANCY
}

\section{DE BOTHA}

Department of Nursing

University of the Orange Free State

\section{R VAN DER MERWE}

Lecturer, Department of Nursing

University of the Orange Free State

\section{OPSOMMING}

Vaginale infeksies kom algemeen by swanger vroue voor. By die Primêre Gesondheidsorg klinieke word geskiedenisvasstelling en beraming van kliniese beeld gebruik as metode om die veroorsakende organisme van vaginale infeksie te diagnoseer. Die akkuraatheid van hierdie metode word in die studie ondersoek met behulp van mikroskopiese natsmere om die veroorsakende organismes te identifiseer. Die resultaat soos verkry, met behulp van geskiedenisvasstelling en beraming van kliniese beeld, word vergelyk met die resultaat verkry nadat ' $n$ natsmeer van die vaginale afskeiding onder ' $n$ mikroskoop ondersoek is.

Sewentig respondente het deelgneem aan die studie. In 48,6\% van die gevalle het die diagnoses van die veroorsakende organisme, soos bepaal deur die twee verskillende metodes, ooreengestem. In 51,4\% van die gevalle het die diagnoses egter nie ooreengestem nie. So is Candida albicans infeksie by ondermeer 10 persone gediagnoseer, terwyl 3 Trichomonas vaginalis infeksie en sewe Gardnerella vaginalis infeksie gehad het. By 26 persone is Trichomonas vaginalis infeksie gediagnoseer, terwyl 15 eintlik Candida albicans infeksie en 11 Gardnerella vaginalis infeksie gehad het.

Vaginale infeksies, veroorsaak deur Gardnerella vaginalis is nie in enige van die gevalle met behulp van geskiedenisvasstelling en beraming van kliniese beeld gediagnoseer nie, terwyl dit in 11 gevalle voorgekom en met behulp van mikroskopiese ondersoek gediagnoseer is.

\begin{abstract}
Pregnant women are prone to vaginal infection. At Primary Health Care Clinics diagnosis of causative organism of vaginal infections is made by using history-taking and assessment of clinical picture methods. The accuracy of these methods is investigated in this study by comparing the results obtained by historytaking and assessment of clinical picture with that which is obtained by examining wet mount specimens under a microscope.
\end{abstract}

Seventy respondents participated in the study. In 48,6\% cases, the diagnosis of the causative organism, as identified by the two different methods, were similar. In 51,4\% of the cases the diagnosis differed. Candida albicans infection was diagnosed by 10 respondents, while 3 actually had Trichomonas vaginalis infection and seven had Gardnerella vaginalis infection.

Trichomonas vaginalis infection was diagnosed in 26 cases, while 15 were actually due to Candida albicans and 11 due to Gardnerella vaginalis. 
Vaginal infections, caused by Gardnerella vaginalis was not diagnosed in any of the cases while the historytaking and assessment of clinical picture methods were used. It did occur in 11 cases and was diagnosed by the method of examining wet mount slides.

\section{INTRODUCTION}

Vaginal infection is extremely common amongst women and accounts for a large number of consultations at Primary Health Care Clinics. Pregnant women are even more prone to develop vaginal infections due to the physiological and hormonal changes that occur in pregnancy. Persistent vaginal infection in a pregnant woman, can lead to genital and oral thrust of the neonate (after birth), neonatal respiratory tract infection, preterm labour, urinary tract infection and chronic cervicitis and postpartum endometritis.

Different micro-organisms that cause vaginal infection are sensitive to different drugs and if an incorrect drug is given, the organism may develop resistance to the drug. In the case of Candida albicans, the condition will be aggravated if the patient is treated with antibiotics instead of a fungicide (Neuberg, 1995:61).

The researcher observed, in Primary Health Care Clinics, that the causative organisms of vaginal infections are mainly diagnosed as being Candida albicans or Trichomonas vaginalis. The organism Gardnerella vaginalis is seldom diagnosed as the causative organism. The method used to make these diagnosis is history-taking together with clinical assessment.

Several methods can be used to diagnose the causative organisms of vaginal infections. The following are the most popular:

\section{Diagnosis by means of laboratory tests}

A sample of the discharge is taken and sent to a laboratory for incubation and isolation of cultures. This is an accurate method of diagnosing the organism, but is time consuming and expensive.

\section{History-taking and clinical assessment}

A thorough history concerning the discharge is obtained from the client, after which a clinical examination, usually a speculum examination is carried out. The genitals are inspected, as well as the colour, consistency and odour of the discharge. The diagnosis of the causative organism is made according to the specific characteristics associated with the different organisms. These are the following:

- Candida albicans infection: in females it usually causes vulva irritation with a scanty, watery discharge, or in severe cases, a profuse, thick, white and curdy discharge. On examination, the vulva may be red and edematous. A speculum examination will reveal thick, white, cheese-like patches adhering to the vaginal mucus (Nel, 1995; Olds et al. 1996).

- Trichomonas vaginalis is associated with complaints of a copious, thin, yellow or yellow-green discharge, which may be frothy in appearance. The discharge usually smells offensive. On examination, acute inflammation and excoriation of the vulva, perineum and even the inner thighs may be seen. The vaginal walls and the cervix may be covered with a thin discharge which, when removed, reveals severe reddening of the mucosal surfaces, thus the term "strawberry cervix" (Freeman, 1995; Ament \& Whalen, 1996).

- Gardnerella vaginalis infection is characterised by a grey, homogeneous, adherent vaginal discharge that is usually malodorous. Unlike other causes of vaginal discharge, this infection is not associ 
ated with pruritis, dysuria or dyspareunia. The main complaints are the presence of the vaginal discharge which may be profuse, and the odor that is often described as "fishy" (Nel, 1995; Freeman, 1995; Olds et al. 1996).

Using the history-taking and clinical assessment method to identify the causative organisms seems quite easy, but unfortunately, it is complicated by the following:

- The typical picture, as described above, does not always appear as clearly as described. Weinberger \& Harger (1993) supported by Pastorek, Cotch, Martin \& Eschenbach (1996) indicate that the typical clinical picture associated with Trichomonas vaginalis infection is only seen in $10 \%$ of women with vaginal infection. The well-known "white, curdy" discharge associated with Candida albicans infection is only seen in a small number of patients (Deutchman, Leaman and Thomason, 1994).

- In some patients the vaginal discharge may not cause symptoms. Govender, Hoosen, Moodley, Moodley \& Strum (1996) indicate that Bacterial vaginosis (caused by Gardnerella vaginalis) may be asymptomatic.

Occurrence of more than one type of organism simultaneously, the so-called "mixed picture". O’Dowd (1991) points out that Gardnerella vaginalis may be found simultaneously with either Candida albicans and/or Trichomonas vaginalis.

Microscopic examination of wet mount preparation

With this method, a preparation of the discharge and certain solutions is made, and this is examined under a microscope, the causative organism is identified by its characteristics. The following criteria are used to identify organisms:

\section{KOH-prepared slides}

- If a "fishy" odor occurs after adding a drop of $10 \% \mathrm{KOH}$, Gardnerella vaginalis is diagnosed.

. When the $\mathrm{KOH}$-prepared slide is examined under the microscope, and hives and spores (Figure 1) are identified, the organism is Candida albicans. The $\mathrm{KOH}$ devolves the vaginal epithelial cells to expose the fungus.

\section{Sodium chloride-prepared slides}

- When the slide is examined under the microscope and movement is seen, the organism is Trichomonas vaginalis. It should be noted that this characteristic of the Tri-

Figure 1: Hives and spores of Candida albicans (Nel, 1995:335)

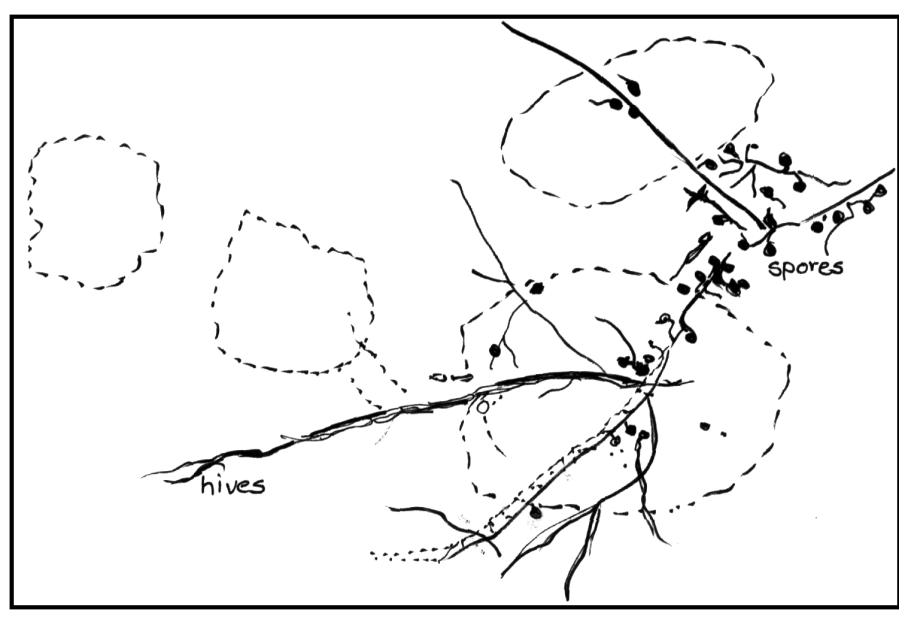

chomonas vaginalis is soon lost and therefore the examination of a smear must take place immediately after it has been prepared.

- If "clue cells" or speckled cells are identified (Figure 2), the vaginal discharge is due to Gardnerella vaginalis since the coccobacilli adheres to the epithelial cells and this causes the speckled appearance (Eschenbach, 1992:139).

This method of diagnosis of micro-organisms is a reliable method since the distinctive characteristics of the micro-organisms can clearly be identified. The examiner though has to be skilled in the use of a microscope and has to be knowledgeable on the identification of the distinctive characteristics. 
Figure 2: Clue cells covered with Gardnerella vaginalis (Nel, 1995:335)

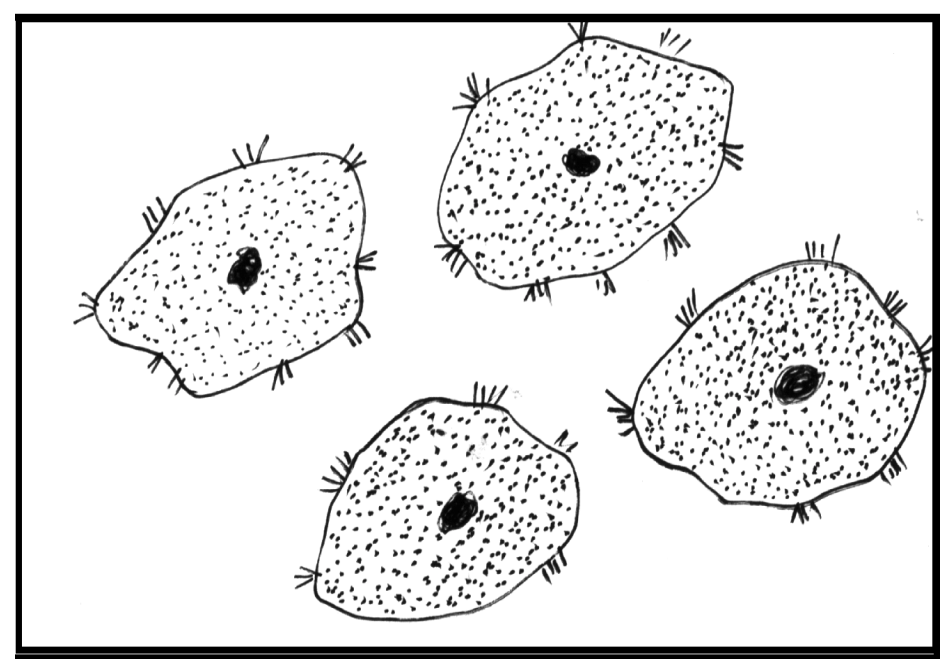

\section{PROBLEM STATEMENT}

As indicated, diagnosing the causative organism of vaginal infections by using the method of historytaking and clinical assessment, which is used in most Primary Health Care Clinics, can be complicated if the clinical picture deviates from the described picture. The accuracy of diagnosis of the causative organism of vaginal discharge when using the history-taking and clinical assessment method was investigated in this study.

It was assumed that professional personnel are competent in diagnosing the causative organism with the history-taking and clinical assessment method. The study was undertaken as part of a postgraduate programme.

\section{PURPOSE OF THE STUDY}

The purpose of the study was to compare the results of diagnosis made by using history-taking and clinical assessment method with that made by using a microscope and examining wet mount specimens.

This examination gave information on how accurate diagnosis were when using a specific method.

\section{RESEARCH DESIGN}

A non-experimental, descriptive approach was applied while a survey method was used.

\section{RESEARCH TECHNIQUE}

Biophysical measurement was used since microscopic examination of prepared specimens was done.

Validity of biophysical measurement was ensured by using a calibrated, electric microscope and by identifying the organisms by means of described, well-known, distinctive, microscopic characteristics. The researcher is proficient in the use of a microscope.

The reliability of identifying the organisms on wet mount preparations was enhanced by the researcher who had previously been evaluated on identifying organisms on wet mount specimens by an experienced medical officer. This was done before the onset of this study. During these evaluations, the researcher correctly identified all the organisms of the given specimens on different occasions.

Reliability of measurement was further enhanced by the fact that the researcher examined all the specimens. The wet mount preparations were examined immediately after they were obtained in order not to miss characteristics such as mobility, which disappears shortly after exposure to unfavorable surroundings.

\section{SAMPLING METHOD AND SAMPLE}

Respondents were identified by means of convenience sampling. Pregnant women who visited two different antenatal clinics during May 1998 and who met the inclusion criteria were selected and asked for voluntary participation. 


\section{Inclusion criteria}

The respondent:

- had to be more than 12 weeks pregnant.

By this time most of the physiological changes in her body had already taken place;

- had to have a complaint about a vaginal infection.

Respondents were informed that participation was voluntary and they were informed about the purpose and implications (such as obtaining a sample of vaginal discharge during the PAP-smear procedure) of the study.

Seventy participants took part in the study.

\section{VALIDITY AND RELIABILITY}

Validity of the study was ensured by using a scientific method, microscopic examination, to identify causative micro-organisms of vaginal infections.

Reliability of the study was further enhanced by having one person, the researcher, prepare and ex- amine the wet mount specimens.

\section{DATA COLLECTION}

Patients who visited two different Primary Health Care Clinics for antenatal care and who met the inclusion criteria were approached for invitation to participate in the study. After consent was obtained, the respondents were seen by midwives for routine check-ups as well as management of the vaginal discharge.

After each respondent was interviewed by the midwife, the researcher performed the PAP-smear procedure, during which a specimen of the discharge was simultaneously obtained. At the time of the study, taking of PAP-smears was a routine procedure.

The researcher then immediately prepared the wet mount smears and examined it under the microscope. Thereafter the midwife and researcher compared the results and reached agreement on which organism was present in the specific case so that the appropriate treatment could be described.

Table 1: Comparison of diagnosis of causative organisms $(n=70)$

\begin{tabular}{|c|c|c|}
\hline $\begin{array}{l}\text { DIAGNOSIS BY HISTORY } \\
\text { AND CLINICAL PICTURE }\end{array}$ & $\begin{array}{l}\text { DIAGNOSIS BY } \\
\text { MICROSCOPE }\end{array}$ & COMHENTS \\
\hline $\begin{array}{l}\text { Candida abicans } \\
31 \text { respondents }(44,3 \%)\end{array}$ & $\begin{array}{l}\text { Candida albicans } \\
21 \text { respondents }(67,7 \%) \\
\text { confirmed }\end{array}$ & $\begin{array}{l}\text { From the } 31 \text { respondents in } \\
\text { column one: } \\
3 \text { respondents }(9,68 \%) \text { had } \\
\text { Trichomonas vaginalis instead } \\
\text { of Candida abicans } \\
7 \text { respondents }(22,58 \%) \text { had } \\
\text { Gardnerella vaginalis instead } \\
\text { of Candida abicans }\end{array}$ \\
\hline $\begin{array}{l}\text { Trichomonas vaginalis } \\
39 \text { respondents }(55,7 \%)\end{array}$ & $\begin{array}{l}\text { Trichomonas vaginalis } \\
13 \text { respondents }(33.33 \%) \\
\text { confirmed }\end{array}$ & $\begin{array}{l}\text { From the } 39 \text { respondents in } \\
\text { column one: } \\
15 \text { respondents }(38,5 \%) \text { had } \\
\text { Candida abicans instead of } \\
\text { Trichomonas vaginalis } \\
11 \text { respondents }(28,2 \%) \text { had } \\
\text { Gardnerella vaginalis instead } \\
\text { of Trichomings vaginalis }\end{array}$ \\
\hline $\begin{array}{l}\text { Gardnerella vaginalis } \\
\text { No diagnosis made }\end{array}$ & $\begin{array}{l}\text { Gardnerella vaginalis } \\
18 \text { respondents }(25,7 \%) \\
\text { confirmed }\end{array}$ & $\begin{array}{l}18 \text { respondents ( } 25,7 \%) \\
\text { having Gardnerella vaginalis } \\
\text { were missed with history- } \\
\text { taking and clinical assessment } \\
\text { method. }\end{array}$ \\
\hline
\end{tabular}




\section{RESULTS}

A comparison of the diagnosis of causative organisms obtained by the two different methods is in Table 1.

With reference to Table 1, it is clear that the diagnosis of Candida albicans as causative organism were incorrect in 10 (ten) cases. In three of the cases, Trichomonas vaginalis was the causative organism and in seven cases, it was Garnerella vaginalis.

Concerning the 39 respondent who were diagnosed as having Trichomonas vaginalis infection, 13 were confirmed as having Trichomonas infection. In 15 cases the wet mount method identified Candida albicans and in 11 cases Gardnerella vaginalis as causative organism.

It should be noted that through the wet mount method, Gardnerella vaginalis infection was diagnosed in 18 cases, while there was no diagnosis of this organism when using the history-taking and clinical assessment method.

In total, $48,6 \%$ of the diagnoses made by historytaking and clinical picture correspond with that of the researcher, but more than half $\mathbf{( 5 1 . 4 \% )}$ of the diagnoses did not correspond.

In no case, more than one organism simultaneous (mixed picture) occurred in this study.

\section{RECOMMENDATIONS}

- The competence of midwives and professional nurses in diagnosing causative organisms by means of history-taking and clinical assessment method, should be evaluated.

The competence of midwives regarding the history-taking and clinical assessment method was not evaluated in detail in this study, since it is expected that a professional midwife will be updated and clinical competent regarding practical procedures.

Microscopes should be considered standard equipment in Primary Health Care Clinics and professional nurses and midwives should be trained to use it in the appropriate situations. It can be used to diagnose the causative organism in vaginal infections, but also, amongst others, in identifying the ferning capacity of the cervical mucus with ovulation (Olds et al. 1996:138), or to carry out the ferning test in order to diagnose rupture of membranes (Olds et al. 1996:484).

\section{CONCLUSION}

Chronic vaginal infection in pregnant women may lead to several complications as indicated in the introduction.

In this study, more than half of the causative organisms of vaginal infections in the sample, diagnosed by history-taking and clinical assessment method, differed from the diagnosis made by using wet mount preparations.

These differences can be either due to the fact that the method itself is not as reliable as thought, or it might be due to lack of competence in using the method.

To improve maternal and child health, this situation should be challenged. Challenged by the professional nurses and midwives as well as by managers of health care.

\section{REFERENCES}

AMENT, LA \& WHALEN, E 1996: Sexually transmitted diseases in pregnancy: Diagnosis, impact and intervention. JOGNN, 25(8).

BURNS, N \& GROVE, SK 1993: The practice of nurs 
ing research conduct, critique and utilization; $2^{\text {nd }} \mathrm{ed}$.

Philadelphia: WB Saunders Co.

DEUTCHMAN, ME; LEAMAN, DJ \& THOMASON, JL 1994: Vaginitis: Diagnosis is the key. Patient Care, September 1994.

FREEMAN, SB 1995: Common genitourinary infections. JOGNN, 24(8).

GOVENDER, L; HOOSEN, AA; MOODLEY, J; MOODLEY, P \& STRUM, AW 1996: Bacterial vaginosis and associated infections in pregnancy. International Journal of Gynecology and Obstetrics, 55.

NEL, JT 1995: Kernverloskunde en ginekologie met eksamenwenke vir M.B.Ch.B. Isando: Heinemann Voortgesette Onderwys.

NEWTON, ER; PIPER, J \& PEARIS, W 1997: Bacterial vaginosis and intra-amniotic infection. American Journal of Obstetrics.

O’DOWD, TC 1991: New light on vaginitis. Update, June 1991

OLDS, SB; LONDON, ML \& LADEWIG, PW 1996: Maternal newborn nursing. Menlopark: Addison-Wesley Publishing Co.

PASTOREK, JG; MARTIN, DH; COTCH, MF \& ESCHENBACH, DA 1996: Clinical and microbiological correlates of vaginal trichomonas during pregnancy.

Clinical Infectious Diseases, 23, 1996. 